\title{
Estimation of Outdoor Gamma Dose Rates and Lifetime Cancer Risk in Akoko Region, Ondo State, Southwestern Nigeria.
}

\author{
Asere A. $\mathrm{M}^{1 *}$ and Ajayi I. $\mathrm{R}^{2}$ \\ ${ }^{1,2}$ Deparment of Physics and Electronics, Adekunle Ajasin University, Akungba Akoko, Ondo State, Nigeria. \\ ${ }^{2}$ Crawford University, Igbesa, Ogun State, Nigeria. \\ Corresponding author e-mail: adeola.asere@aaua.edu.ng
}

\begin{abstract}
Exposure to ionizing radiation even at low doses may cause damage to the genetic material in the cells that can result in the development of radiation induced cancer many years later. In this study, an in-situ measurement of gamma exposure levels was carried out in 19 towns in Akoko region, Ondo State Southwestern* Nigeria. Gamma dose rates were measured using a well calibrated Inspector 1000 detector. A total of 1097 points were surveyed across the area. The dose rates obtained varies from 0.03 to $0.18 \mu \mathrm{Svh}{ }^{-1}$ with a mean value of $0.086 \pm 0.02 \mu S v h^{-1}$
\end{abstract}

The data obtained were used to realize the outdoor gamma radiation map of the study area.

Keywords: Akoko Region, Excessive lifetime cancer, Gamma dose rates, Inspector 1000

\section{Introduction}

Ionizing radiation is the term used to describe the transfer of energy through space or through a material medium in the form of electromagnetic waves or subatomic particles that are capable of causing ionization in matter, that is, capable of changing neutral atoms into charged atoms called ions by removing or sometimes adding electrons. When ionizing radiation passes through matter, energy is imparted into the matter as ions are formed; the energy imparted is quantized in term of dose. In biological tissues, the processes of changing atoms through ionization also changes the molecules containing those atoms and it may thus cause damage to the cells containing those molecules. The radiation environment is formed by a flux of elementary particles and energy. The radiation is either of man-made; generated by the decay of unstable naturally occurring elements or of extra-terrestrial origin. Ionization is due to alpha, beta, gamma and neutron radiation. Natural sources of radiation comprise that part of the natural radiation environment that has always accompanied life on earth [1]. Many naturally occurring elements have radioactive isotopes but only potassium, uranium and thorium decay series have radioisotopes that produce gamma rays of sufficient energy and intensity to be measured by gamma ray spectrometry because they are relatively abundant in the natural environment.

Cosmic radiation consisting mainly of high energy particles from the sun and outer space interacts with the earth's atmosphere and give rise to a secondary radiation of particles and gamma rays which prevail at the earth's surface. Cosmogenic radionuclides are produced through the interaction of cosmic rays with atoms in the atmosphere and do not contribute significantly to radiation absorbed dose. Terrestrial radiation results from the primordial radionuclides in rocks that were synthesised during the creation of the earth. This is the most significant sources of potassium, uranium and thorium and their decay products.

A number of authors have reports on measurement of indoor and outdoor gamma dose in Nigeria [2, 3, 4] but data are sparse on gamma exposure levels in Akokoland area. In other words, there have not been well established data to assess the exposure levels, dose and the risk to people there. Consequently, there is a general lack of awareness on knowledge of radiological hazard and exposure levels by the public. Thus the aim of this work is to determine the gamma dose rates levels in outdoor environment and the risk associated with exposure.

\section{Study Area}

The research study area is Akoko region of Ondo State, Southwestern* Nigeria. Akoko region lies between longitude $5^{\circ} 30^{\prime}$ and $6^{\circ} 30^{\prime}$ of Greenwich meridian and latitudes $7^{\circ} 20^{\prime}$ and $7^{\circ} 45^{\prime}$ north of the equator. It comprises of four local government areas and occupies about 835500 square kilometres of land. The region is made up of undulating lowlands with isolated hills. The study area lies within the transition zone of the tropical equatorial climate of Southern Nigeria and tropical continental climate of Northern Nigeria. The total amount of annual rainfall is about $1200 \mathrm{~mm}$ and mean temperature of about $21^{\circ} \mathrm{C}$. The vegetation is made up of purely forest to the South and savannah woodlands to the North. The mean annual relative humidity is above $80 \%$.

The study area is situated in the basement complex of Southwestern* Nigeria, generally referred to as migmatite gneiss quartzite complex [5]. The rock types in the study areas include: grey gneiss, granite gneiss, quartzite and other subordinates like charnockites and a few pegmatitic bodies, one of the other minor ferromagnesian mineral present include biotite. The granite gneiss is the predominant rock type, grey gneiss was also found as a massive rock body in the study area. 


\section{Material And Method}

The instrument used to perform the environmental radiation survey is a high performance hand held Inspector 1000 Digital Handheld Multichannel Analyzer specially designed for environmental screening and field measurements applications requiring dose and count rate measurements. It is an easy to use Sodium Iodide scintillation detector with s/n: 13000399 manufactured by Canberra industries. It has an energy range of $50 \mathrm{KeV}$ to $3 \mathrm{MeV}$, minimum dose rates equivalent $\left(\mathrm{H}^{*} 10\right)$ of $10 \mathrm{nSvh}^{-1}$ and maximum dose rates equivalent $\left(\mathrm{H}^{*} 10\right)$ of $100 \mathrm{mSvh}^{-1}$. Although the inspector 1000 can obtain pulse height distribution, it was used for dose rate reading only in this study [6]. The detector was well calibrated at CANBERRA, France Industry laboratory.

The in-situ gamma dose rates measurements were performed by placing the detector at a height of one meter above the ground surface with the probe facing downward and allow 6 minutes of measurement time [7]. Three readings were taken consecutively in a location and the average recorded to represent the value for the location. The outdoor measurements were performed on roads, pavements, over soil in parks, gardens, near public buildings such as hospitals, schools, offices, shops [8]. A fixed distance measurement of $1 \mathrm{~m}$ was used. At least 25 to 150 survey points in each town were measured and more than 1000 survey points were covered all together in the study area.

\subsection{Gamma Dose Rates}

\section{Result And Discussion}

The in-situ gamma dose rates was measured directly by the instrument and do not need any calculation. The mean gamma dose rates varies from one community to another with the highest in Ifira Akoko with $0.120 \pm 0.02 \mu \mathrm{Svh}^{-1}$ and lowest in Ogbagi Akoko with $0.05 \pm 0.01 \mu \mathrm{Svh}^{-1}$ and an average of $0.086 \pm 0.02 \mu \mathrm{Svh}^{-1}$. The survey in the 19 communities recorded a range of $(0.03$ to 0.18$) \mu \mathrm{Svh}^{-1}$. The mean dose rates, standard deviation, and range of values for each town are used to draw the outdoor gamma radiation map for the area presented in "Fig 1". The radiological map present the map of the study area and the gamma dose rate data obtained in each town surveyed. Such map has been presented in a previous research [8]. The values obtained in this research were in agreement with those reported in typical researches in Nigeria $[9,3]$.

\subsection{Annual effective Dose}

The mean absorbed dose rates for each town were used to calculate the annual effective dose received by people in their outdoor environment. Since the instrument used for gamma survey in this research measured directly the equivalent dose on the depth $10 \mathrm{~mm}$ of human tissue $\left(\mathrm{Svh}^{-1}\right)$, the annual effective dose, $\mathrm{He}\left(\mathrm{mSv}^{-1}\right)$ was calculated using (1) [2]:

$H e=D \times T \times F$

Where $\mathrm{D}$ is mean dose rate for each town $\left(\mathrm{nSvh}^{-1}\right), \mathrm{T}$ is the time of the year $\left(8760 \mathrm{hy}^{-1}\right)$ and $\mathrm{F}$ is the outdoor occupancy factor $(0.2)$ that is, the people spent $20 \%$ of their time outdoor. "Table 1 " present the annual effective dose, the number of measurements for each town and excess lifetime cancer risk values. The estimated value of annual effective dose varies from 0.088 to $0.210 \mathrm{mSvy}^{-1}$ with a mean of $0.150 \mathrm{mSvy}^{-1}$. The resulting average was lower than the worldwide annual average of $0.48 \mathrm{mSv}$ [10]. "Fig 2" presents the variations of annual effective dose in each town surveyed. The highest peak was recorded in Ifira followed by Epinmi Akoko. The dose recorded in these areas could be attributed to the Uranium rich granite gneiss rock which was* in abundant in the study area and the local soil composition.

\subsection{Excess Lifetime Cancer Risk}

The risk to an actual person from a given dose depends on that person's age at the time of the exposure and on their gender [11]. The Excess Lifetime Cancer Risk (ELCR) was calculated based upon calculated values of annual effective dose equivalent and a life span of 70 years continuous exposure to gamma radiation using (2) [4]:

$$
E L C R=H e \times D L \times R F
$$

Where DL is duration of life, and RF is risk factor or fatal cancer per sievert. For low dose background radiations which are considered to produce stochastic effects, ICRP 60 uses values of 0.05 for the public exposure. Estimated lifetime cancer risk ranges from $0.307 \times 10^{-3}$ to $0.736 \times 10^{-3}$ with a mean value of $0.525 \times 10^{-3}$ which was higher than the standard value of $0.29 \times 10^{-3}$. These values matches well with the report of Ononugbo et al., (2015) in Nigeria with a range of $0.75 \times 10^{-3}$ to $0.885 \times 10^{-3}$. 
Table 1: Annual effective dose (AED) and Excess lifetime cancer risk (ELCR)

\begin{tabular}{|l|l|l|l|}
\hline $\begin{array}{l}\text { Location } \\
\text { (Akokoland) }\end{array}$ & No of Measurement & AED mSvy & \\
\hline Ikare & 140 & 0.193 & ELCR $^{-1} 0^{-3}$ \\
\hline Arigidi & 50 & 0.201 & 0.675 \\
\hline Ajowa & 60 & 0.123 & 0.705 \\
\hline Ilkaram & 40 & 0.102 & 0.429 \\
\hline Ayegunle & 45 & 0.131 & 0.356 \\
\hline Etioro & 40 & 0.140 & 0.460 \\
\hline Oke-Agbe & 60 & 0.121 & 0.491 \\
\hline Ogbagi & 50 & 0.088 & 0.423 \\
\hline Irun & 40 & 0.123 & 0.307 \\
\hline Oke Oka & 60 & 0.151 & 0.429 \\
\hline Supare & 60 & 0.152 & 0.527 \\
\hline Iwaro Oka & 60 & 0.149 & 0.533 \\
\hline Akungba & 90 & 0.147 & 0.521 \\
\hline Oba & 40 & 0.140 & 0.515 \\
\hline Ikun & 40 & 0.140 & 0.491 \\
\hline Epinmi & 72 & 0.207 & 0.491 \\
\hline Isua & 60 & 0.205 & 0.724 \\
\hline Ifira & 50 & 0.210 & 0.717 \\
\hline & & & 0.736 \\
\hline
\end{tabular}

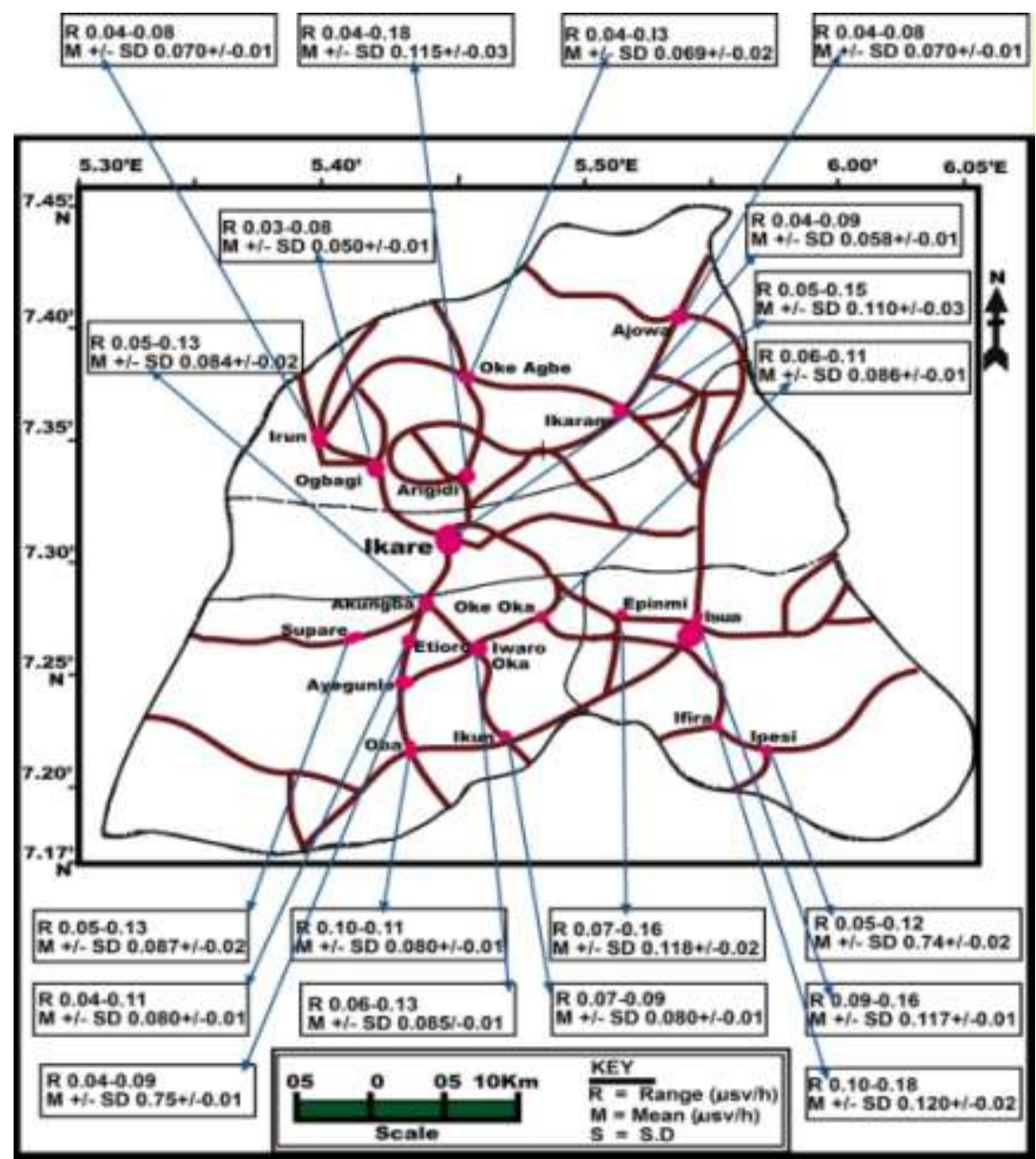

Figure 1 Radiological Map of Outdoor Gamma Radiation Map of Akoko Region.

Figure 1 present the Gamma Outdoor Radiation Map of Akoko region obtained by in-situ measurements with a portable NaI detector in 19 towns of Akoko region, Ondo State, Southwestern* Nigeria. For each town, $\mathrm{R}$ is the range of the measurement, $\mathrm{M}$ is the mean gamma dose rate and SD is the standard deviation. 


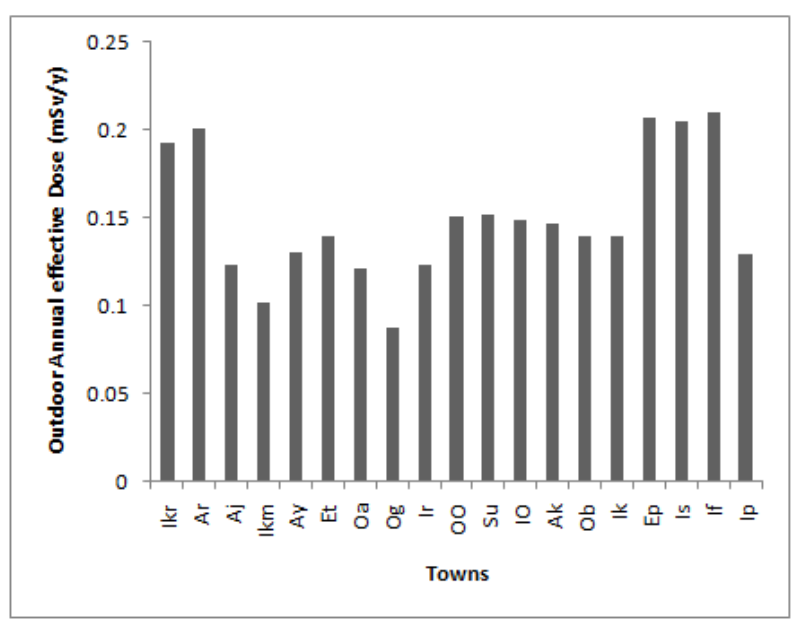

Figure 2 Outdoor Annual effective Dose in Each Town Surveyed,

Figure 2 shows the outdoor annual effective doses in each town surveyed.

Key: $\mathrm{Ikr}=\mathrm{Ikare}, \mathrm{Ar}=$ Arigidi, $\mathrm{Aj}=$ Ajowa $, \mathrm{Ikm}=\mathrm{Ikaram}, \mathrm{Ay}=$ Ayegunle, $\mathrm{Et}=$ Etioro, $\mathrm{Oa}=$ Oke Agbe,

$\mathrm{Og}=$ Ogbagi, Ir = Irun, OO = Oke Oka, Su = Supare, IO = Iwaro Oka, Ak = Akungba, Ob = Oba, Ik = Ikun, Ep $=$ Epinmi, Is $=$ Isua, If $=$ Ifira, Ip = Ipe.

\section{Conclusions}

In the present work, 1097 in situ gamma dose rates measurements were performed in 19 towns of Akoko region of Ondo State, Southwestern* Nigeria. The highest radiation level was obtained in Ifira Akoko with a mean of $0.12 \mu \mathrm{Sv} / \mathrm{h}$ corresponding to annual effective dose of $0.210 \mathrm{mSvy}^{-1}$. This could be attributed to the Uranium rich granite gneiss rocks which was* in abundant in the study area and the local soil composition. Average lifetime cancer risk was $0.53 \times 10^{-3}$ which is large compared to the worldwide average of $0.29 \times 10^{-3}$. Most radiation exposure involves low doses delivered over long periods. The internationally accepted solution to studies of cancer risk has been to assume that the relationship is linear for low doses. That is, any radiation dose has a detrimental effect, however small. The dose received in these areas was lower than the recommended $1 \mathrm{mSv}$ for the members of the public. The occupants of these areas are therefore relatively safe. The radiological map and data presented in this study area serve as a comprehensive baseline data which could be used as a reference for future research work.

\section{Funding}

This research did not receive any specific grant from funding agencies in the public, commercial, or not-forprofit sectors.

\section{Conflict of Interest}

The authors declared no conflict of interest.

\section{References}

[1]. IAEA, Safety Standard Series . Assessment of Occupational exposure due to external sources of radiation. 1999.

[2]. A.A Sadiq, E.H. Agba, Indoor and outdoor ambient radiation levels in Keffi, Nigeria. Facta Universitatis series, working and living environmental protection. 9(1), 2012, 19-26.

[3]. N.N. Jibiri, S.T.U. Obarhua, Indoor and outdoor gamma dose rate exposure levels in major commercial building material distribution outlets and their radiological implications to occupants in Ibadan, Nigeria. J. National Sci. Res. 3(3), 2013, 25-31.

[4]. C.P. Ononugbo, G.O. Avwiri, G. Tutumeni, Estimation of indoor and outdoor Effective doses from gamma dose rates of residential buildings in Emelogu village in Rivers State, Nigeria. Int. Res. J. of Pure and Appl. Phys. 3(2), 2015, 18-27.

[5]. M.A. Rahaman, O.O. Ocan, The nature of the granulite facies metamorphism in Ikare Area, Southwestern, Nigeria. In:Precambrian geology of Nigeria. GSN, 1978, 157-162.

[6]. C. Supitha, K. Chutima, T. Shinji, S. Napakans, P. Karnwalee, P. Chanis, Terrestrial gamma radiation in Phuket Island, Thailand. Engineering Journal. 15(4), 2011, 65-72. doi:10.4 186/ej.2011.15.4.65.

[7]. IAEA-TECDOC-1363, Guidelines for radioelement mapping using gamma ray spectrometry data, 2003.

[8]. A. Clouvas, S. Xanthos, M. Antonopoulou-Domis, Radiological maps of outdoor and indoor gamma dose rates in Greek urban areas obtained by in situ gamma spectrometry, Rad Prot Dosi. 112(2), 2004, 267-275.

[9]. I.O. Olarinoye, I. Sharifat, A.N. Baba-Kutigi, M.T. Kolo, K.. Aladeniyi, Measurement of background gamma radaiation levels at two tertiary institutions in Minna, Nigeria. J. of Appl. Sci. and environ management. 14(1), 2010. 59-62.

[10]. UNSCEAR, Sources and effects of ionizing radiation. Report to the general assembly without scientific annexes, 2000.

[11]. IAEA, Radiation, people and the environment, 2004. 